\title{
Fungal pyogranulomatous encephalitis in a dog with leishmaniosis
}

\author{
Encefalite piogranulomatosa micótica em um cão com leishmaniose
}

\author{
Gisele Fabrino Machado ${ }^{1 *}$ Rosemeri de Oliveira Vasconcelos $^{1}$ Maria Cecília Rui Luvizotto ${ }^{1}$ \\ Terezinha Cristina Cândido ${ }^{2}$
}

-NOTE-

\section{ABSTRACT}

A case of pyogranulomatous micotic encephalitis in a one-year old, female, Fila Brasileiro dog is reported. Gross examination of the cerebrum revealed a softened haemorrhagic area in the right frontal cortex and on the cut surface of the left hemisphere, which affected the white matter and deep cortical areas. The diagnosis of multifocal mycotic pyogranulomatous encephalitis was obtained by the histopathological examination, which showed the presence of macrophages, giant cells, haemorrhage and brownish septate hyphae diffusely distributed within the tissue and invading vessel lumina. Identification of amastigotes forms in popliteus lymphonode imprint confirmed infection by Leishmania sp. Mycotic infection in the brain of this dog was related to a concurrent leishmaniosis, an immunosuppressive disease.
\end{abstract}

Key words: leishmaniasis, mycotic encephalitis, dog.

\section{RESUMO}

É relatado um caso de encefalite piogranulomatosa em um cão fêmea de um ano de idade, da raça Fila Brasileiro. Ao exame macroscópico do cérebro, evidenciou-se área amolecida e hemorrágica no córtex frontal direito e na superfície de corte do hemisfério esquerdo, afetando a substância branca e áreas corticais profundas. $O$ diagnóstico de encefalite piogranulomatosa micótica multifocal foi realizado através de exame histopatológico, que mostrou a presença de macrófagos, células gigantes, focos de hemorragia e hifas septadas de coloração marrom, com distribuição difusa e invadindo a luz de vasos. A identificação de formas amastigotas "no imprint" de linfonodo poplíteo confirmou o diagnóstico de leishmaniose. A infecção micótica no cérebro deste cão foi relacionada com a ocorrência concomitante de leishmaniose, uma doença imunossupressora.

Palavras-chave: leishmaniose, encefalite micótica, cão.

Several different fungal organisms have been shown to cause meningitis and encephalitis in both large and small animals. Fungal organisms commonly reported to infect the central nervous system of small animals are Cryptococcus neoformans (WILKINSON 1979; O'TOOLE et al., 2003), Blastomyces dermatiditis (BREIDER et al., 1988), Histoplasma capsulatum (MEADOWS, 1992), Coccidioides immitis (BURTCH, 1998) Cladophialophora bantiana (AÑOR et al., 2001), several species of Aspergillus including A. fumigatus and A. terreus (MULLANEY et al., 1983), and Fusarium solani (EVANS et al., 2004).

Phaeohyphomycosis is a human and animal infection caused by dematiaceous (darkly pigmented) fungi, defined as those that have melanin or melaninlike pigment in their cell walls (DILLEHAY et al., 1987;

\footnotetext{
${ }^{1}$ Departamento de Clínica, Cirurgia e Reprodução Animal, Curso de Medicina Veterinária, Universidade Estadual Paulista (UNESP), Faculdade de Odontologia de Araçatuba (FOA), Rua Clóvis Pestana, 793, 16050-680, Araçatuba, SP, Brasil. Email: giselem@fmva.unesp.br.

2Programa de Pós-graduação em Ciência Animal (Fisiopatologia Médica e Cirúrgica), Curso de Medicina Veterinária, UNESP-FOA, SP, Brasil.

*Autor para correspondência.
} 
BOULJIHAD et al., 2002). The infection with aggressive fungus has a high mortality rate, primarily related to its poor response to currently available antifungal therapy (TUNUGUNTLA et al., 2005). Most reported cases of cerebral phaeohyphomycosis have occurred in immunocompetent patients; however, some case reports and experimental data have suggested that cellular immune deficiency is a risk factor (BRANDT \& WARNOCK, 2003). Being a parasite, Leishmania ensures its own survival by modulating the host immune system either by inducing immunosuppression or by promoting pro-parasitic host functions (AWASTHI et al., 2004). Studies of Leishmania infections in mice indicate that resistance or susceptibility to the disease is associated with the development of Th1 or Th2-type response, respectively (LOCKSLEY \& SCOTT, 1991). Visceral leishmaniasis presents vigorous Th2 immune response, which is mainly characterized in human by augmented expression of IL-4, polyclonal B cell activation, intense hypergammaglobulinemia and production of antileishmanial IgE antibodies (ALMEIDA et al., 2005). Prolonged latent infection with Leishmania sp results in cell-mediated immunosuppression that could be related to the expression of IL-10 (SANTOS-GOMES et al., 2002). Compromised hosts with impaired Tlymphocyte or macrophage function are prone to develop CNS infections caused by intracellular pathogens as bacteria (e.g., Nocardia), viruses (e.g. herpesvirus), parasites (e.g., $\boldsymbol{T}$. gondii) and fungus as Aspergillus sp (CUNHA, 2001).

A one-year old female dog of the Fila Brasileiro breed, had been presenting clinical signs of apathy, ataxy and cough for 8 days and eventually died before clinical attendance. Icterus, swollen lymph nodes, splenomegalia, pulmonary congestion and whitish dots in the kidney cortex were observed at necropsy. Cytology for leishmaniasis was positive at popliteus lymphonodus imprint stained with Panótico rápido (similar to Diff Quik ${ }^{\circledR}$, a Giemsa stain). In the brain, meninges were diffusely opaque and congested; the superficial blood vessels of the cerebral cortex were hyperemic; a softened haemorrhagic area was observed in the right frontal cortex and on the cut surface of the left hemisphere, which affected the white matter and deep cortical areas. Oral cavity and teeth, ear canals and nasal sinuses, were examined, and no evidence of inflammation or trauma was found in any of these locations. Pulmonary lesions suggestive of mycotic infection were not observed. Only alveolar congestion was observed in the histopathological examination of lungs. Microscopically, numerous brown, oblong, segmented branching hyphae and extensive pyogranulomatous inflammation were identified throughout the cerebral lesion and in adjacent blood vessels. Hyphae was easily visualized in hematoxilineosin stain.

Seizures are common reflection of a variety of intracranial physiologic abnormalities in dogs. The localization and extension of lesion in frontal lobes are also associated with seizures (BAGLEY \& GAVIN, 1998). Whereas intracranial tumours can occur in young dogs and cats they typically occur in middle aged to older animals (MOORE et al., 1996). Since the lesion of the brain of this dog at gross examination suggested a diagnosis of neoplasia, complementary tests were not performed. The diagnosis of multifocal mycotic pyogranulomatous encephalitis was obtained by histopathological examination, which was characterized by the presence of neutrophils, mononuclear and giant cells, haemorrhage and brownish septate hyphae diffusely distributed within the tissue (Figure 1) and invading vessel lumina. Much of the nervous tissue damage is caused by vascular invasion of the organism and associated with inflammatory reaction, leading secondarily to infarction.

The source of infection in this case was not identified. The route of entry has been speculated to be nasal, as suggested by KROHNE (2000) as the principal route of infection. In this case, no systemic spread was identified, indicative of lack of hematogenous spread. Although fungal infections themselves are relatively frequent, actual granulomatous masses due to fungal infections are rare (DUBEY et al., 2005). Cladophialophora species are highly neurotropic, and Cladophialophora bantiana (synonym = Xylohypha bantiana or C. trichoides) is the most commonly identified agent (OSIYEMI et al., 2001). The immune response during $\boldsymbol{L}$. infantum infection has been widely studied. Susceptible dogs show poor lymphoproliferative responses to specific antigen (PINELLI et al., 1994; MARTINEZ-MORENO et al., 1995) and the immunosuppressive nature of the disease, though antigen-specific, is an early event following infection (DE LUNA et al., 1999). Based on the morphologic aspects, the agent is believed to be a fungus of the Cladosporium gender, which, in the case under discussion, had no trouble to invade the encephalon due to down regulation of protective Thelper type 1 adaptive immune responses associated with visceral leishmaniasis.

\section{ACKNOWLEDGMENTS}

Dr. Márcio Botelho de Castro for the help with the photograph.

Ciência Rural, v.36, n.4, jul-ago, 2006. 


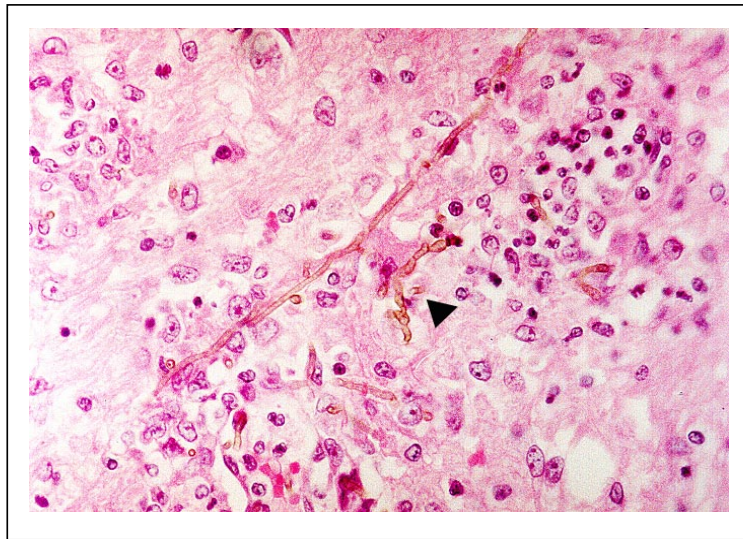

Figure 1 - Histological section of brain cortex where brownish hyphae (arrow head), gliosis and neutrophils are observed (H-E). Objective 40X.

\section{REFERENCES}

ALMEIDA, M.A. et al. Antileishmanial antibody profile in dogs naturally infected with Leishmania chagasi. Vet Immunol Immunopathol, v.106, n.1-2, p.151-8, 2005.

AÑOR, S. et al. Systemic phaeohyphomycosis (Cladophialophora bantiana) in a dog - clinical diagnosis with stereotactic computed tomography-guided brain biopsy. J Vet Intern Med, v.15, p.257-261, 2001.

AWASTHI, A. et al. Immune response to leishmania infection. Indian J Med Res, v.119, n.6, p.238-258, 2004.

BAGLEY, R.S.; GAVIN, P. Seizures as a complication of brain tumours in dogs. Clinical Techniques in Small Animal Practice, v.13, n.3, p.179-1184, 1998.

BOULJIHAD, M. et al. Pyogranulomatous meningoencephalitis associated with dematiaceous fungal (Cladophialophora bantiana) infection in a domestic cat. J Vet Diagn Invest, v.14, n.1, p.70-72, 2002.

BRANDT, M.E.; WARNOCK, D.W. Epidemiology, clinical manifestations, and therapy of infections caused by dematiaceous fungi. J Chemother, v.15, p.36-47, 2003.

BREIDER, M.A. et al. Blastomycosis in cats: five cases (19791986). J Am Vet Med Assoc, v.193, p.570-572, 1988.

BURTCH, M. Granulomatous meningitis caused by Coccidioides immitis_in a dog. J Am Vet Med Assoc, v.212, n.6, p.827-829, 1998.

CUNHA, B.A. Central nervous system infections in the compromised host: a diagnostic approach. Infect Dis Clin North Am, v.15, n.2, p.567-590, 2001.
DE LUNA, R. et al. Early suppression of lymphoproliferative response in dogs with natural infection by Leishmania infantum. Vet Immunol Immunopathol, v.70, p.95-103, 1999.

DILLEHAY, D.L. et al. Cerebral phaeohyphomycosis in two dogs and a cat. Vet Pathol, v.24, p.192-194, 1987.

DUBEY, A. et al. Intracranial fungal granuloma: analysis of 40 patients and review of the literature. Surg Neurol, v.63, n.3, p.254-260, 2005.

EVANS, J. et al. Intracranial fusariosis: A novel cause of fungal meningoencephalitis in a dog. Vet Pathol, v.41, p.510-514, 2004.

KROHNE, S.G. Canine systemic fungal infections. Vet Clin North Am Small Anim Pract, v.30, n.5, p.1063-1090, 2000.

LOCKSLEY, R.M.; SCOTT, P.A. Helper T-cell subsets in mouse leishmaniasis: induction, expansion and effector function. Immunol Today, v.12, n.3, p.A58-A61, 1991.

MARTINEZ-MORENO, A. et al. Humoral and cell-mediated immunity in natural and experimental canine leishmaniasis. Vet Immunol, v.48, p.209-220, 1995.

MEADOWS, R.L. et al. Diagnosis of histoplasmosis in a dog by cytologic examination of CSF. Vet Clin Pathol, v.21, n.4, p.122-125, 1992.

MOORE, M.P. et al. Intracranial tumours. Vet Clin North America: Small and Pra, v.26, n.4, p.759-777, 1996.

MULLANEY, T.P. et al. Disseminated aspergillosis in a dog. J Am Vet Med Assoc, v.182, p.516-518, 1983.

O'TOOLE, T.E. et al. Cryptococcosis of the central nervous system in a dog. J Am Vet Med Assoc, v.222, n.12, p.17221725, 2003.

OSIYEMI, O.O. et al. Cerebral phaeohyphomycosis due to a novel species: report of a case and review of the literature. Transplantation, v.71, n.9, p.1343-1346, 2001.

PINELLI, E. et al. Cellular and humoral response in dogs experimentally and naturally infected with Leishmania infantum. Infect Immunol, v.62, p.229-235, 1994.

SANTOS-GOMES, G.M. et al. Cytokine expression during the outcome of canine experimental infection by Leishmania infantum. Vet Immunol Immunopathol, v.88, p.21-30, 2002.

TUNUGUNTLA, A. et al. Multiple brain abscesses caused by Cladophialophora bantianum: a challenging case. Tenn Med, v.98, n.5, p.227-228, 2005.

WILKINSON, G.T. Feline cryptococcosis: a review and 7 case reports. J Small Anim Pract, v.20, p.749-768, 1979. 